\title{
The influence of aging treatment on the microstructural and mechanical behavior by ultra-micro hardness tester in Ni-rich NiTi alloy
}

\author{
A influência do tratamento por envelhecimento no comportamento \\ microestrutral e mecânico por ensaio de ultramicrodureza em uma liga \\ de NiTi rica em Ni
}

\author{
1 Naiara Vieira Le Sénéchal naiaravls@gmail.com \\ 2 Rodolfo Teixeira \\ 3 Patrícia Freitas Rodrigues \\ 4 Shimeni Baptista Ribeiro \\ ${ }^{5}$ Andersan dos Santos Paula
}

\footnotetext{
Instituto Militar de Engenharia. Departamento de Ciência dos Materiais - Área de Materiais Metálicos.

Instituto Militar de Engenharia. Departamento de Ciência dos Materiais - Área: Materiais Metálicos.

Universidade Coimbra, CEMMPRE, Departamento de Engenharia Mecânica.

Centro Universitário de Volta Redonda - UniFOA.

Instituto Militar de Engenharia. Departamento de Ciência dos Materiais - Área: Materiais Metálicos.
}

\begin{abstract}
The present study aims to assess the superelasticity behavior in Ni-rich NiTi alloy wire produced by rotary forging process. The thermomechanical process involved four steps of hot working at $800^{\circ} \mathrm{C}$, two steps of cold working with solution heat treatment at $800^{\circ} \mathrm{C}$ between them, and subsequently a solution heat treatment $\left(950^{\circ} \mathrm{C}\right.$ during 2 hours) followed by aging treatment at 350, 400 and $450^{\circ} \mathrm{C}$ during 30 minutes. $X$-ray diffraction (XRD) and instrumented ultra-micro hardness testers evaluated the present phases at each aged sample and were compared with their mechanical behavior by ultramicrohardness technique. The results put in evidence the work-hardening effect on a forged condition associated with the final step of cold rotary forging. The solution treatment promotes stress relaxation and precipitate dissolution. The sample heat-treated shows the presence of the precipitated $\left(\mathrm{Ni}_{4} \mathrm{Ti}_{3}\right)$ and $\mathrm{R}$ phase. The presence of these precipitates is beneficial because precipitation-hardening increases the yield strength of austenite, which in turn contributes to better functional stability.
\end{abstract}

\section{Keywords:}

Shape memory alloys; NiTi; Thermomechanica process; Synchrotron radiation; Heat treatments.

Como você deve citar?

LE SÉNÉCHAL, Naiara Vieira et al. The influence of aging treatment on the microstructural and mechanical behavior by ultra-micro hardness tester in Ni-rich NiTi alloy. Cadernos UniFOA, Volta Redonda (RJ), v. 16, n. 47, p. 43 - 51, dez, 2021.

\section{Resumo}

O presente estudo tem como objetivo avaliar o comportamento da superelasticidade em fios de liga de NiTi ricos em Ni produzidos por meio do processo de forjamento rotativo. 0 processo termomecânico envolveu quatro etapas de trabalho a quente a $800^{\circ} \mathrm{C}$, com duas etapas de trabalho a frio com tratamento térmico de solubilização a $800^{\circ} \mathrm{C}$ entre elas, e posteriormente um tratamento térmico de solubilização $\left(950^{\circ} \mathrm{C}\right.$ durante 2 horas) seguido de tratamento de envelhecimento a 350,400 e $450^{\circ} \mathrm{C}$ durante 30 minutos. 0 ensaio de Difração de Raios X (DRX) e ultra-microdureza instrumentados avaliaram as fases presentes em cada amostra envelhecida que foram comparados com seu comportamento mecânico através da técnica de ultramicrodureza. Os resultados evidenciaram o efeito de endurecimento por trabalho em uma condição forjada associada à etapa final do forjamento rotativo a frio. 0 tratamento térmico proposto promove a redução da tensão e a dissolução de precipitados. A amostra tratada termicamente mostra a presença do precipitado $\left(\mathrm{Ni}_{4} \mathrm{Ti}_{3}\right)$ e da fase R. A presença desses precipitados é benéfica porque o endurecimento por precipitação aumenta a resistência ao escoamento da austenita, que por sua vez contribui para uma melhor estabilidade funcional.

\section{Palavras-chave:}

Ligas com memória de forma; NiTi; Processos Termomecânicos; Radiação Síncroton; Tratamentos Térmicos. 
Many factors can interfere on some materials final characteristics (phase transformations, shape memory effect or its superelasticity at a given working condition), namely: thermal and thermo-mechanical treatments; the $\mathrm{Ni}$ and $\mathrm{Ti}$ content; alloying elements addition; the presence of impurities such as $\mathrm{C}, \mathrm{N}$ and/or $\mathrm{O}$; and microstructure. Therefore, follow up the chemical composition, and the thermo-mechanical process variables are mandatory [1-6]. NiTi processing needs to have both hot and cold forming, since surface finishing, microstructure refinement and improvement of the mechanical properties are achieved during the cold processing [5,7-9]. Thus, when it is desired to obtain distinct functional properties such as superelasticity and shape memory effect, these alloys require a proper thermal treatment after the cold forming step. As the heat treatment temperature decreases, the presence of plastic deformation in the material and austenitic phase resistance increases. However, a decrease in the ductility is also observed; therefore, it improves the superelasticity effect, reduces the residual strain while increasing the capacity to absorb energy resulting in the prevention of permanent deformation [10-12]. In Ni-rich Ni-Ti alloys more effective in promoting R-phase formation. Because of the precipitation phenomena $\left(\mathrm{Ni}_{4} \mathrm{Ti}_{3}\right)$, the $\mathrm{R}$-phase can also be observed during aging treatment. Due to association with a large lattice deformation, these precipitates promote a resistance to formation of B19'. [8,13-15]. Gall et al. (2001)[16] observed the mechanical properties through analyzing the areas resulted by the instrumented nanoindentation test based on prior microstructural conditions, between loading and unloading curves. This test allows us to determine dissipated energy, material hardness, the plastic and elastic working behavior (dissipated and recovery energies), and recoverable energy mechanisms that occur internally within the microstructure.

Since the extracted data in this graphic representation allows us to infer the mechanical behavior of the resulting microstructural condition associated with heat treatment applied to the sample. When stress is applied to the austenite field, the induced-stress martensite is formed, but after unloading, the deformed material reverts to austenite. [18-21]

Therefore, this study aimed to evaluate the superelastic development, the influence of aging treatment, and correlate the resulting phase at room temperate in Ni-rich NiTi alloy thin bars produced by rotary forging.

\section{MATERIAL AND METHODS}

Ni-rich NiTi alloy produced by the melting process in a vacuum induction furnace (VIM) at "Instituto Tecnológico da Aeronaútica" (ITA) - Brazil, with approximately 50.8 at. \% Ni was used in this study. The ingot slice was cut by electroerosion to get samples with $90 \mathrm{~g}$ and then recast in the arc melting furnace to obtain cylindrical samples for the thermomechanical processing by rotary forging, which started with a sequence hot forming and finished by cold-work sequences interspersed with steps of heat treatment, as shown in Figure 1.

The material was solubilized at $950^{\circ} \mathrm{C}$ for 120 minutes followed by quenching into the water at room temperature, and/or with further aging treatment at $350^{\circ} \mathrm{C}, 400^{\circ} \mathrm{C}, 450^{\circ} \mathrm{C}$ for 30 minutes, followed by quenching into the water at room temperature. The solubilization treatment adopted of $950^{\circ} \mathrm{C} / 120 \mathrm{~min}$ indicates a possible dissolution of precipitates and matrix homogenization. Furthermore, it is possible to obtain a greater fraction of B2 at room temperature, which is a premise for solubilization for aging treatment. [22, 23] 
Figure 1 - Schematic thermomechanical process. Forging: a) 4 hammers and b) 2 hammers

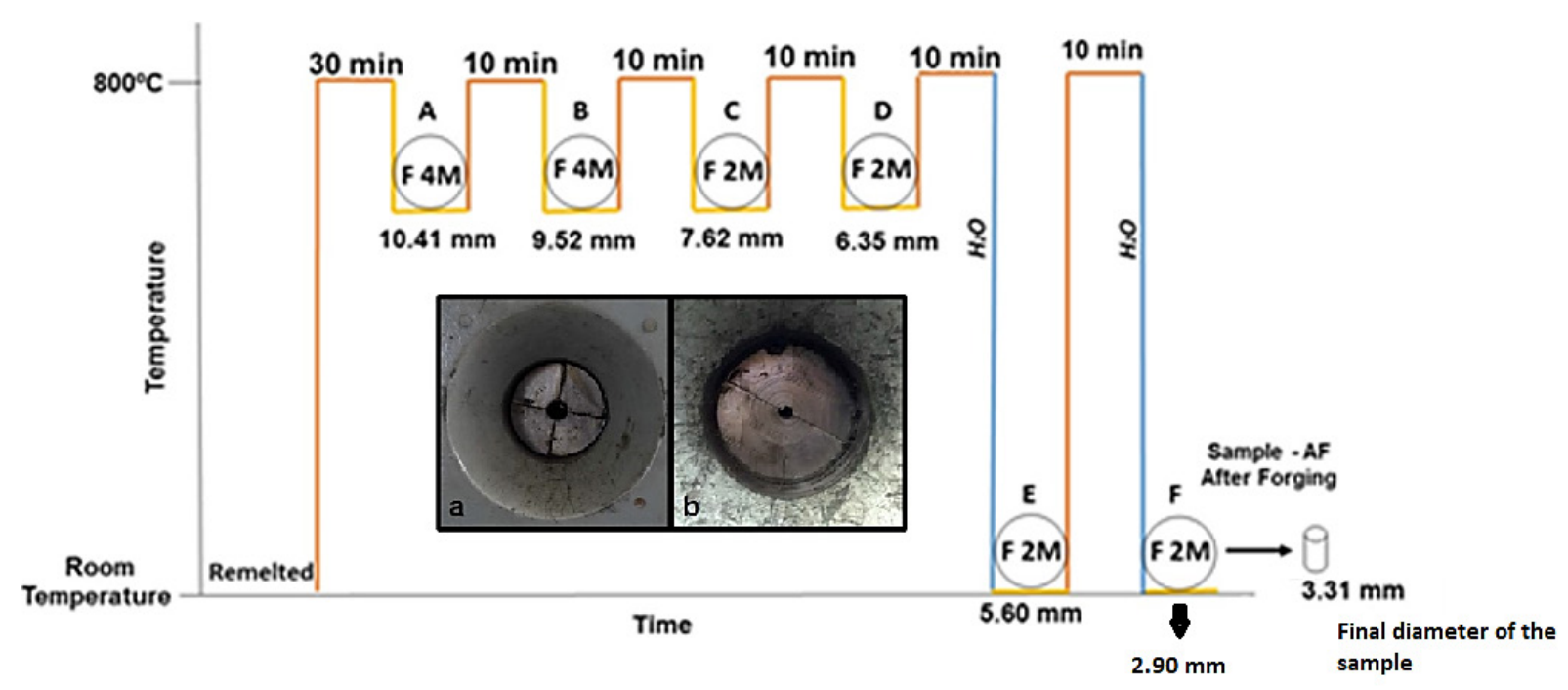

Fonte: Rodrigues (2018)

Structural characterization of the specimens was performed using the XRD test (Shimadzu (XRD6000)) diffractometer Co-Ka. The XRD test was performed at $20^{\circ} \mathrm{C}$, controlled temperature. Mechanical properties were evaluated by Vickers indenter at $20^{\circ} \mathrm{C}$, using an instrumented ultra-micro hardness tester (Shimadzu, DUH-211S) applying maximum force (F) of $25 \mathrm{gf}$. The results are the average value of five measurements obtained from loading curves, such as indentation hardness (Hit), contact depth (hc), maximum indentation depth associated with maximum force (hmax), permanent indentation depth after the complete removal of the load (hp) and depth of the indentation considering the perfect elastic return, obtained by the intersection of the straight line, coincident with the beginning of unloading, with the unloading curve (hr).

\section{RESULTS AND DISCUSSION}

From XRD results (Figure 2) is possible to verify that both samples - After Forging sample (AF) and Solubilized sample (SOL) - are austenitic at $20^{\circ} \mathrm{C}$ (room temperature - controlled temperature). Although differences between their behavior could be observed, and are highlighted below:

- AF sample shows evidence of (110)B2 peak in $49.852 \theta$, and the SOL sample shows (110)B2 peak in $49.62 \theta$; the (110)B2 peak at AF sample has higher intensity and a thin shape while the SOL sample has an inverse characteristic. Due to heating, it was evident that the austenite peak (110)B2 shifted to smaller $2 \theta$ angles in the SOL sample, corresponding to larger $d$-spacing. Besides, the intensity decreasing may be explained due to grain growth during solution heat treatment as supposed by larger $\mathrm{d}$-spacing values. Therefore, revealing that this homogenization was efficient for the following aging steps adopted for this work.

- Aged Sample at $350^{\circ} \mathrm{C} \_30 \mathrm{~min}$, the presence of a mixture of B2 and R-phase was identified. Due to precipitation phenomena ( $\mathrm{Ni} 4 \mathrm{Ti} 3$ ), the R-phase also can be observed. The aged samples at 400 and $450^{\circ} \mathrm{C} \_30$ min show the $2 \theta$ position of (110)B2 peak close to the SOL sample (110)B2 $2 \theta$ position. Besides, the broadening of the (110)B2 peak may be associated with the presence of precipitates. These precipitates are distributed in the B2 matrix, affecting the mechanical characteristics of the alloy. The technique applied did not allow us to identify smaller precipitates. 
Figure 2 - XRD patterns: AF - After Forging (black line) and SOL - Solubilized (red line), Heat Treated Samples: $350^{\circ} \mathrm{C} \_30 \mathrm{~min}$ (blue line), $400{ }^{\circ} \mathrm{C} \_30 \mathrm{~min}$ (green line) and $450^{\circ} \mathrm{C} / 30 \mathrm{~min}$ (orange line).

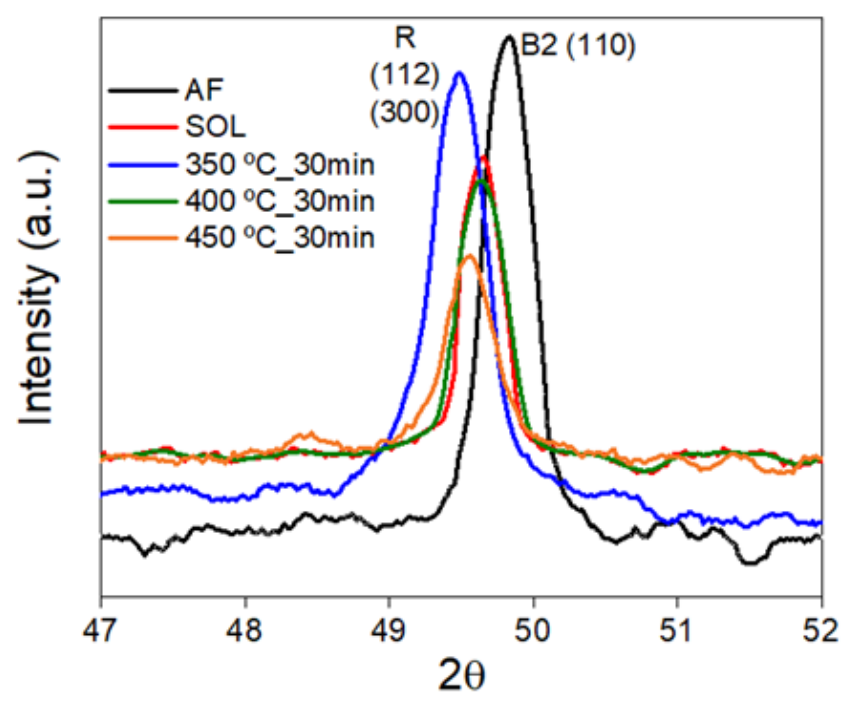

Fonte: Autores (2021)

Ni-rich Ni-Ti alloys can exhibit superelastic properties resulting from B2-B19' stress-induced transformation. For heat treatments at high temperatures, there is enough thermal energy to allow rapid diffusion of $\mathrm{Ni}$ and $\mathrm{Ti}$ atoms in the matrix. On the other hand, at a lower temperature nucleation rate is higher, but the diffusion coefficients are low. Both processes are equilibrated at intermediate temperatures $\left(350-450^{\circ} \mathrm{C}\right)$ to achieve maximum precipitation rates. [24-26] The size of the Ni4Ti3 precipitates increases with increasing aging temperature and aging time.[27-29]

Figure 3 demonstrates five measurements of ultra-micro hardness of the before (AF sample) and after solution treatment at $950^{\circ} \mathrm{C}$ for 2 hours (SOL sample) and different aged samples $(350,400$, and $450^{\circ} \mathrm{C}$ for 30 minutes). The mechanical behavior (Figure 3 ) was analyzed by graphic interpretation, considering the behavior of curves. Analysis of nanoindentation curves conjugated to the analysis of XRD patterns (Figures 2 and 3 ), it is possible to support its behavior. When comparing AF sample with SOL sample results (Figure $4(a, b)$ ), it is possible to observe that both samples have similar behavior, may be associated with B2 at room temperature, even AF showed a displacement in B2 peak. The aged samples are subjected to Ni4Ti3 precipitation that introduces stress fields, thus giving changes in transformations condition, and its respective phase presents at each heat treatment performed (Figures 2 and 3), as described below.

- For $350^{\circ} \mathrm{C}$ their behavior is analyzed (Figure $3(\mathrm{c})$ ), which has plateau region, that suggests to occurs two effects isolated or simultaneously: i) reorientation of variants of the R-phase (Figure 2) and/or ii) martensitic transformation by stress-induced (B2 $\otimes \mathrm{R})$.

- For 400 and $450^{\circ} \mathrm{C}$ no significant difference was identified. These results were not expected. All these aging temperatures showed B2 at room temperature (Figure 3). However, the reason for the absence of the plateau region could be interpreted as being a result of high maximum force and together with the absence of R-phase, which the tension associated with the reorientation of the R-phase variants is lower than a stress-induced transformation from B2. 
Figure 3 - Loading and unloading curves instrumented nanoindentation at $20^{\circ} \mathrm{C}$ - Samples: (a) AF After Forging, (b) SOL - Solubilized, (c) $350^{\circ} \mathrm{C} / 30 \mathrm{~min}$, (d) $400^{\circ} \mathrm{C} / 30 \mathrm{~min}$ and (e) $450{ }^{\circ} \mathrm{C} / 30 \mathrm{~min}$.
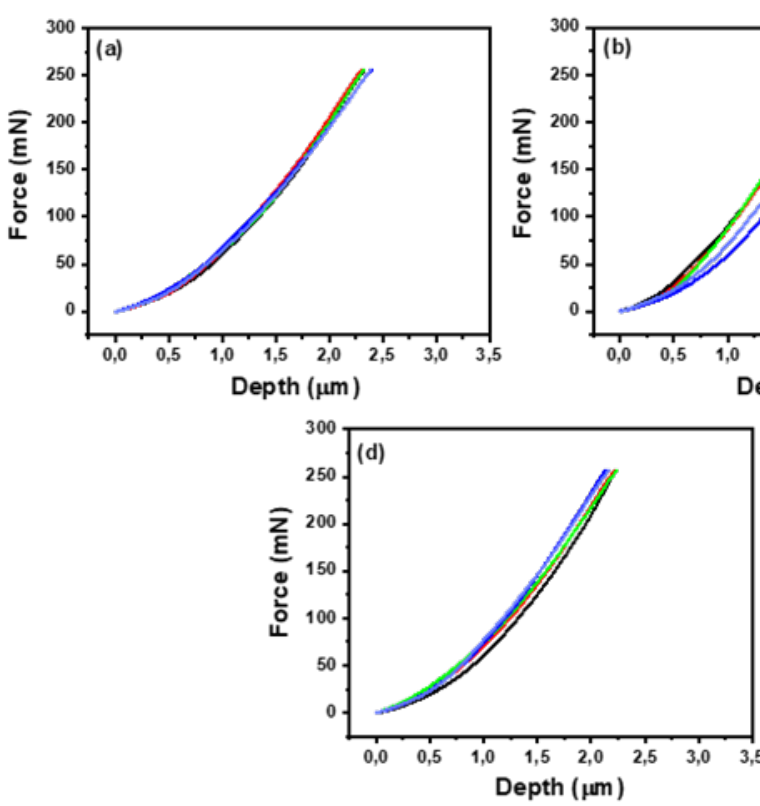
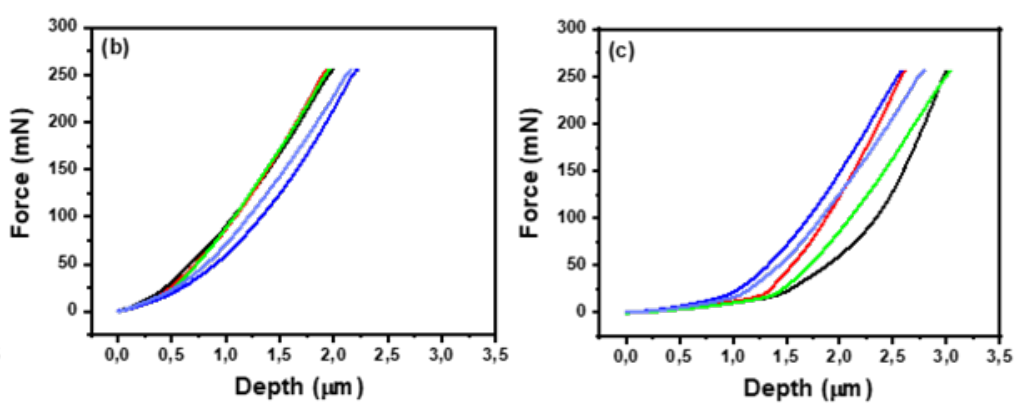

Fonte: Autores (2021)

Some properties from ultra-micro hardness tester of the AF sample, SOL sample, and different aged samples $\left(350,400,450^{\circ} \mathrm{C}\right.$ for 30 minutes) are shown in Table 1.

The permanent indentation depth after removal of the test force (hp) reveals lower mean values to $\mathrm{AF}$ and $\mathrm{SOL}$ samples. Among the aged samples, $350^{\circ} \mathrm{C}$ showed higher mean values.

The propriety indentation hardness, Hit, is a measure of the resistance to permanent deformation or damage. In qualitative terms, it can be related to the yield strength for advanced deformation [30]. The formula to obtain $\left(\mathrm{H}_{i t}\right)$ is $\mathrm{H}_{i t}=\mathrm{Fmax} / \mathrm{Ap}$, where Fmax is maximum force, and Ap is projected (cros$s$-clauseal) area of contact between the indenter and the test piece determined. For triangular indenter $\left(115^{\circ}\right), A p=23.96 \times \mathrm{h}_{c}{ }^{2}$. Higher mean values are checked for SOL and AF sample. It can be associated with the presence of the austenitic phase. The same behavior was checked to aged samples, higher mean values to the aged samples at 400,450 and $350^{\circ} \mathrm{C}$. [31-32] The $350^{\circ} \mathrm{C}$ sample shows lower mean values, and it could be due to the tension associated with the reorientation of variants of the R-phase (which is presumably present in this aging temperature, it is placed in levels lower than B19' and much lower than the level of stress-induced transformation at from austenitic phase (B2)). [33] These results corroborate with those observed to hp. 
Table 01 - Permanent indentation depth after removal of the test force $\left(h_{p}\right)$, indentation hardness $\left(H_{i t}\right)$, elastic work (Welastic) and plastic work (Wplastic) for: AF - After Forging, SOL - Solubilized, $350^{\circ} \mathrm{C} /$ $30 \mathrm{~min}, 400^{\circ} \mathrm{C} / 30 \mathrm{~min}$, and $450^{\circ} \mathrm{C} / 30 \mathrm{~min}$.

\begin{tabular}{ccccc}
\hline & \multicolumn{2}{c}{$\mathbf{A ~}_{\mathrm{p}}[\boldsymbol{\mu} \mathbf{m}]$} & \multicolumn{3}{c}{$\mathrm{H}_{\mathrm{it}}\left[\mathbf{N} / \mathbf{m m}^{2}\right]$} \\
\hline $\mathrm{A}$ & $\mathrm{SD}$ & $\mathrm{A}$ & $\mathrm{SD}$ \\
\hline $\mathrm{SOL}$ & 1.201 & 0.098 & 178 & 2690 \\
\hline $350^{\circ} \mathrm{C} / 30 \mathrm{~min}$ & 1.183 & 0.305 & 907 & 3110 \\
\hline $400^{\circ} \mathrm{C} / 30 \mathrm{~min}$ & 1.288 & 0.250 & 371 & 1772 \\
\hline $450^{\circ} \mathrm{C} / 30 \mathrm{~min}$ & 1.457 & 0.128 & 327 & 2661 \\
\hline
\end{tabular}

A - Average; SD - Standard Deviation

Fonte: Autores (2021)

\section{CONCLUSIONS}

1. The aging heat treatment performed at 350,400 , and $450^{\circ} \mathrm{C}$ indicated the formation of $\mathrm{Ni} 4 \mathrm{Ti} 3$ in the early stages of precipitation by R-phase identified in XRD measurement.

2. Aging conditions associated with lower heterogeneity precipitates distribution profile was more suitable to induced phase transformation by deformation than the promoted previous deformation by dislocations slip. Thus, the minimum $\left(350^{\circ} \mathrm{C}\right)$ and maximum $\left(450{ }^{\circ} \mathrm{C}\right)$ aging temperature, adopted in this work, promoted an increase of the critical shear stress required for dislocation slip, stabilizing austenite at room temperature due to the $\mathrm{Ni}_{3} \mathrm{Ti}_{4}$ precipitate formation early or later stages with homogeneous distribution trends on the B2 matrix.

3. $350^{\circ} \mathrm{C}$ aged sample showed a mixture of the presence of austenite and R-phase at room temperature.

4. The results indicated that, among the aging, conditions studied, the $350^{\circ} \mathrm{C} / 30 \mathrm{~min}$ sample shows the best conditions for superelasticity associated with low critical stress for the stress-induced martensitic transformation.

5. The instrumented ultra-micro hardness test has demonstrated to be a promising technique to evaluate superelastic behavior. It was identified in the plateau region. However, it may have limitations. It is plausible that the selected maximum force might have influenced the results obtained. These limitations underline evidence of the difficulty of collecting data from hardness.

\section{ACKNOWLEDGMENTS}

LeSénéchal, N.V., acknowledges the funding of Capes. The authors thank FAPERJ for the financial support (APQ-1 2009/02 E-26/110.414/2010, APQ-1 2011-2 E-26/110.269.2012, E-26/111.435/2012) and to CAPES for a MSc. scholarship (S.B.R. and S.B.D. in Brazil, and P.R.F by CsF BEX 11943-13-0 in Portugal). PFR acknowledge the funding of CEMMPRE by Project PTDC/CTM-CTM/29101/2017 POCI-01-0145-FEDER-029101 funded by FEDER funds through COMPETE2020 - Programa Operacional Competitividade e Internacionalização (POCI) and by national funds (PIDDAC) through FCT/MCTES. This 
research was also supported by FEDER funds through the program COMPETE-Programa Operacional Factores de Competitividade and by national funds through FCT-Fundação para a Ciência e a Tecnologia under the project UIDB/EMS/00285/2020. The authors thank Professor Jorge Otubo for donating the starting materials that were produced in the Instituto Tecnológico da Aeronáutica (São José dos Campos, SP - Brazil). The authors thank Professors Ladário da Silva and José Augusto Oliveira Huguenin which allowed the use of the Laboratório Multiusuário de Caracterização de Materiais do Instituto de Ciências Exatas da Universidade Federal Fluminense (ICEx/UFF), in Volta Redonda/RJ - Brazil, for the use of the instrumented ultra-micro hardness equipment for analysis of the samples.

\section{REFERENCES}

[[1] SUZUKI, Y. Fabrication of shape memory alloys. In: Otsuka K and CMW, editor. Shape Mem. Mater. 1st ed., New York: Cambridge University Press, p. 133-48, 1998.

[2] OTSUKA, K.; REN, X. Physical metallurgy of Ti-Ni-based shape memory alloys. Prog Ma-ter Sci, p.50:511-678, 2005. https://doi.org/DOI 10.1016/j.pmatsci.2004.10.001.

[3] KOTHA, RS.; ALLA, RK.; SHAMMAS, M.; RAVI, RK. An Overview of Orthodontic Wires. Trends Biomater Artif Organs, p.28:32-6, 2014.

[4] OTUBO, J.; RIGO, OD.; COELHO, AA.; NETO, CM.; MEI, PR. The influence of carbon and oxygen content on the martensitic transformation temperatures and enthalpies of NiTi shape memory alloy. Mater Sci Eng A, p. 481-482:639-42. 2008. https://doi.org/10.1016/j.msea.2007.02.137.

[5] ZHOU, D.; GAO, Y.; LAI, M.; LI, H.; YUAN, B.; ZHU, M.; A review of shape memory alloy research, applications and opportunities. Mater Sci Eng A, p.56:1078-113, 2015. https://doi.org/10.1016/j.matdes.2013.11.084.

[6] FREITAS RODRIGUES, P. Structural Evolution of Ni-Ti Alloy Wires Produced by Hot and Cold Rotary Forging. Dissertação para obtenção do Grau de Doutor em Ciência e Engenharia de Materiais. Universidade Nova de Lisboa, 2018.

[7] SUN, B.; LIN, J.; FU, MW. Dependence of processing window and microstructural evolu-tion on initial material state in direct electric resistance heat treatment of NiTi alloy. Mater Des, p.139:549-64, 2018. https://doi.org/10.1016/J.MATDES.2017.11.044.

[8] KHALIL-ALLAFI, J.; EGEELER, G.; DLOUHY, A.; SCHMAHL, WW.; SOMSEN, C. On the influence of heterogeneous precipitation on martensitic transformations in a Ni-rich NiTi shape memory alloy. Mater Sci Eng A, p.378:148-51, 2004.https://doi.org/10.1016/j.msea.2003.10.335.

[9] ŚWIEC, P.; ZUBKO, M.; LEKSTON, Z.; STRÓŻ, D. Structure and Properties of NiTi Shape Memory Alloy after Cold Rolling in Martensitic State. Acta Phys Pol A, p. 130:1081-4, 2016. https://doi.org/10.12693/ APhysPolA.130.1081.

[10] NEMAT-NASSER, S.; GUO, WG. Superelastic and cyclic response of NiTi SMA at various strain rates and temperatures. Mech Mater, p.38:463-74, 2006. https://doi.org/10.1016/j.mechmat.2005.07.004.

[11] YEUNG, KWK.; CHEUNG, KMC.; LU, WW.; CHUNG, CY. Optimization of thermal treatment parameters to alter austenitic phase transition temperature of NiTi alloy for medical implant. Mater Sci Eng A, p.383:213-8, 2004. https://doi.org/10.1016/j.msea.2004.05.063. 
[12] HELLER, L.; SEINER, H.; ŠITTNER, P.; SEDLÁK, P.; TYC, O.; KADEŘÁVEK, L. On the plastic deformation accompanying cyclic martensitic transformation in thermomechanically loaded NiTi. Int J Plast, p.111:53-71, 2018. https://doi.org/10.1016/j.ijplas.2018.07.007.

[13] ALLAFI, JK.; REN, X.; EGGELER, G. The mechanism of multistage martensitic transformations in aged Ni-rich NiTi shape memory alloys. Acta Mater, p. 50:793-803, 2002. https://doi.org/10.1016/ S1359-6454(01)00385-8.

[14] SCHMAHL, WW.; KHALIL-ALLAFI, J.; HASSE, B.; WAGNER, M.; HECKMANN, A.; SOMSEN, C. Investigation of the phase evolution in a superelastic NiTi shape memory alloy (50.7 at.\%Ni) under extensional load with synchrotron radiation. Mater Sci Eng A, p.378:81-5, 2004. https://doi.org/10.1016/j.msea.2003.11.081.

[15] FAN, QC.; ZHANG, YH.; WANG, YY.; SUN, MY.; MENG, YT.; HUANG, SK.; et al. Influences of transformation behavior and precipitates on the deformation behavior of Ni-rich NiTi alloys. Mater Sci Eng A, 2017. https://doi.org/10.1016/j.msea.2017.05.107.

[16] GALL, K.; JUNTUNEN, K.; MAIER, HJ.; SEHITOGLU, H.; CHUMLYAKOV, YI. Instrumented microindentation of NiTi shape-memory alloys. Acta Mater, p.49:3205-17, 2001. https://doi.org/10.1016/ S1359-6454(01)00223-3.

[17] MORGAN, N.; WICK, A.; DICELLO, J.; GRAHAM, R. Carbon and Oxygen Levels in Nitinol Alloys and the Implications for Medical Device Manufacture and Durability. Int. Conf. Shape Mem. Superelastic Technol., vol. 683, California: ASM International; p.821-8, 2008. https://doi.org/10.1361/cp2006smst821.

[18] SAGHAIAN, SM.; KARACA, HE.; TOBE, H.; PONS, J.; SANTAMARTA, R.; CHUMLYAKOV, YI.; et al. Effects of $\mathrm{Ni}$ content on the shape memory properties and microstructure of $\mathrm{Ni}$-rich $\mathrm{NiTi}-2 \mathrm{OHf}$ alloys. Smart Mater Struct, p. 25:095029, 2016. https://doi.org/10.1088/0964-1726/25/9/095029.

[19] GALL, K.; SEHITOGLU, H.; CHUMLYAKOV, YI.; KIREEVA, IV.; MAIER, HJ. The Influence of Aging on Critical Transformation Stress Levels and Martensite Start Temperatures in NiTi: Part II-Discussion of Experimental Results. J Eng Mater Technol, p.121:28-37, 1999. https://doi.org/10.1115/1.2815995.

[20] TEIXEIRA, RS.; PAULA, AS.; SANTOS, FS.; RODRIGUES, PF.; BRAZ FERNANDES, FM. Critical Analyses on the Instrumented Ultramicrohardness Results on Aging NiTi Alloy in Distinct Phase Fields, p.109-14, 2018. https://doi.org/10.1007/978-3-319-76968-4_17.

[21] RODRIGUES, PF.; FERNANDES, FMB.; TEIXEIRA, EM.; BAPTISTA, S.; PAULA, AS.; OLIVEIRA, JP. Influence of ageing treatment on the thermophysical characteristics and mechanical properties of forging wire Ni-rich NiTi alloy for superelastic applications. Ciência Tecnol Dos Mater , p.29:e23-6, 2017. https:// doi.org/10.1016/J.CTMAT.2016.07.013.

[22] PELTON, AR.; DICELLO, J.; MIYAZAKI, S. Optimisation of processing and properties of medi-cal grade Nitinol wire. Minim Invasive Ther Allied Technol, p.9:107-18, 2000. https://doi.org/10.3109/13645700009063057.

[23] BATAILLARD, L.; BIDAUX, JE.; GOTTHARD, R. Interaction between microstructure and multiple-step transformation in binary NiTi alloys using in-situ transmission electron microscopy observations. Philos Mag A Phys Condens Matter, Struct Defects Mech Prop, p.78:327-44, 1998. https://doi. org/10.1080/01418619808241907. 
[24] WAGNER, MFX.; DEY, SR.; GUGEL, H.; FRENZEL, J.; SOMSEN, C.; EGGELER, G. Effect of low-temperature precipitation on the transformation characteristics of Ni-rich NiTi shape memory alloys during thermal cycling. Intermetallics, p.18:1172-9, 2010. https://doi.org/10.1016/j.intermet.2010.02.048.

[25] Dynamic Ultra-micro Hardness Tester Instruction Manual, 2009. 